\title{
UDC 332.5
}

\section{PEROVYCH ${ }^{1}$, D. KEREUSH ${ }^{2}$}

${ }^{1}$ Department of Cadastre of Territories, Lviv Polytechnic National University, 12, S. Bandera str., Lviv, Ukraine, 79013 tel.: +38 (032) 2582631, e-mail: lev.perovych@ gmail.com

${ }^{2}$ Department of Cadastre of Territories, Lviv Polytechnic National University, 12, S. Bandera str., Lviv, Ukraine, 79013 tel.: +38 (096) 6752001, e-mail: dariakereush@ gmail.com

\section{TECHNOLOGY OF OPTIMAL SITE SELECTION FOR SOLAR PHOTOVOLTAIC POWER PLANTS USING GIS AND REMOTE SENSING TECHNIQUES}

https://doi.org/

Purpose. The use of ground-mounted solar photovoltaic (PV) power plants to generate electricity has increased substantially worldwide over the past decade. This growth has been driven by policy incentives such as feed-in tariff, as well as low cost and high performance of solar panels. As the use of solar PV farms grows, the need to find the best locations for them will also increase. Optimally siting PV farms is important for maximizing beneficial characteristics of projects while minimizing negative ones. Specifically, optimal siting can maximize projects' power generation while minimizing costs, and environmental, and social impacts. Therefore, the purpose is to design a technology which will realize an integrated framework to evaluate land suitability for the optimal locations of photovoltaic solar power plants. Methods. This study develops a method to utilize a technology for identifying optimal locations for the construction of solar photo-voltaic power plants. It will realize an integrated framework to evaluate land suitability, which is based on a combination of GIS and remote sensing techniques (satellite image classification). The research work is realized by the exclusive use of FOSS (Free and Open Source Software). Results. The reliability of the technology for support decision makers in planning renewable solar energy development is testified and proven in the "pilot" Zastavna district in Chernivtsi region (Ukraine). Data Processing stage is divided into two parts: evaluation and exclusion criteria processing. On the final Map of Land Suitability for Solar PV power plants 58 potential most optimal sites for solar photovoltaic ground-mounted farms`construction were determined with a total area of 7,44 sq.km (743,91 ha) which is $1,2 \%$ of "pilot" district area. To highlight commercial viability of chosen sites it is proposed to estimate how much energy could be produced by establishing on one experimental area a solar PV farm. As a tool for parameters processing and estimation of grid-connected PV solar farm performance, "PVGIS" web application (EC JRC) was used. Therefore, the Annual Performance of PV utility on experimental area was near $250 \mathrm{MWh}$ with an optimal slope (tilt) of the panels $-36^{0}$. Total loss in this case is $20,3 \%$. Scientific novelty and practical significance. A comprehensive analysis of natural factors that influence the choice of the solar farm location, as well as the use of remote sensing and multi-criteria decision analysis methods for obtaining the final map are provided. According to literature reviews, expert opinions and international experiences it is proposed to classify particular criteria into multiple ranges based on suitability. For the first time in Ukraine, in particular, in Zastavna district (Chernivtsi region), reliable data on the optimal location of photovoltaic solar power plant construction are obtained. It should be noted that it is proposed to use only data that is freely available on Internet, free open source software.

Key words: solar photovoltaic power plants; technology; optimal site selection; criteria; GIS; Remote Sensing; FOSS.

\section{Introduction}

Among the renewable power sources, solar power is rapidly becoming popular because it is inexhaustible, clean, and dependable [Georgiou A., Skarlatos D., 2016]. It has also become more efficient since the power conversion efficiency of photovoltaic solar cells has increased. Following these trends, solar power will become more affordable in years to come and considerable investments are to be expected [Sanchez-Lozano et al., 2013; Bahadori and Nwaoha, 2013].

Management and rational use of land resources is currently a pressing issue in the world, in particular in Ukraine. Many land plots in a number of cases are used irrationally and not according to their intended use. The problem of rational land use requires solving a complex of practical tasks based on modern technological and technical means.

One of the solutions is to develop the technology of using these lands for the needs of energy sector, namely, the objects of electricity solar power plants (SPP), which produce electricity through photovoltaic panels.

The use of ground-mounted solar photovoltaic (PV) power plants to generate electricity has been increasing substantially worldwide over the past decade. This growth has been driven by policy incentives such as feed-in tariff, as well as low cost and high performance of solar panels. 
As the use of ground-mounted PV solar power plants grows the need to find the best locations for solar farms will increase as well. The procedures of choosing the site for solar farms location and installation are crucial to their efficiency and financial viability. Overall, optimally siting of PV farms is important for maximizing beneficial characteristics of projects while minimizing negative ones-both of which will facilitate the growth of solar utility.

\section{Goal}

The goal of this work is to design a technology which will realize an integrated framework to evaluate land suitability for the optimal locations of photo-voltaic solar power plants, and is based on a combination of GIS and remote sensing techniques, and multi-criteria decision analysis (MCDA).

As part of this goal, this technology is presented with the intent that others may apply it to their own regions of interest.

\section{Methodology}

According to the main goal of the project a workflow of the research is created (Fig. 1).

The results respond to the needs for intendancies in both, energy sources and GIS technology. A geographic information system (GIS) is a popular and effective decision-making tool for the selection of optimal sites for different types of activities and installations [Carrion et al., 2008; Tegou et al., 2010; Kontos et al.,2005].

Studies using GIS to analyze solar power plant siting consider a number of requirement criteria. These criteria include physical requirements of land, environmental considerations, land-use restrictions, social considerations, and electricalinfrastructure requirements [J. Brewer et al., 2015].

According to literature reviews, expert opinions and international experiences it is proposed to classify particular criteria into multiple ranges based on suitability. Criteria considered for solar PV farm siting are given in Table 1.

The research is realized by the exclusive use of FOSS (Free and Open Source Software) to allow all interested investors, customers and entrepreneurs to follow this technology and create their own Land Availability Map for free. In such a way, analyzing and processing the data is not commercial and could become available for any user. This enables creation of a GIS, which does not depend on money or licenses that provides an opportunity for reproduction, application, and improvement by any interested user.

It is proposed to use PostgreSQL Open Source Database with PostGIS extention, QGIS and LEOWorks Softwares.

PostgreSQL Open Source Database (v.9.5.7) with PostGIS extention is used for Data Modeling and Storage.

QGIS 2.16.3 is used for the data input, management, exchange, analysis and visualization.

LEOWorks 4.0.2339 is software which provides processing of satellite imagery such as satellite image classification, multispectral analysis, procedure pansharpening and calculation of remote sensing-derived indexes.

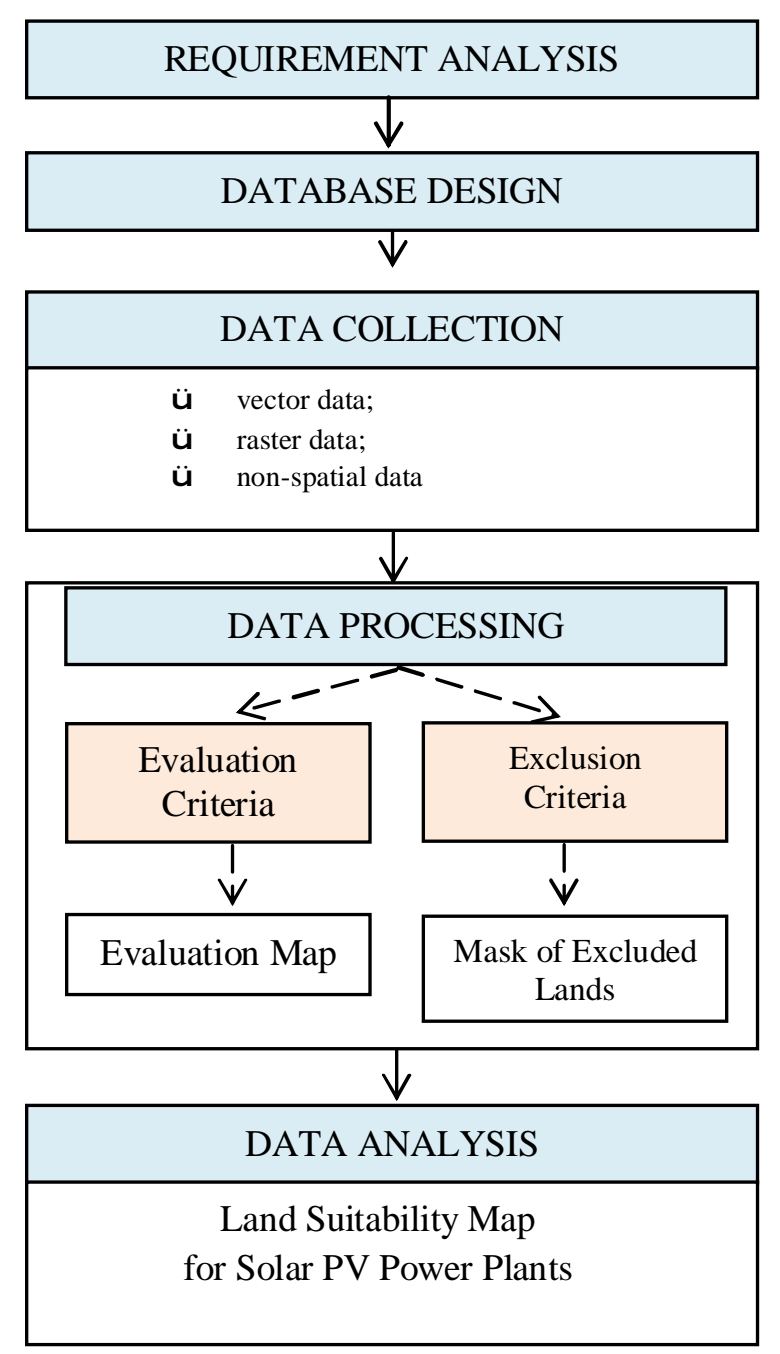

Fig. 1. Workflow of investigation [authors`research] 
Criteria considered for Solar PV power plant siting

Table 1

\begin{tabular}{|c|c|c|}
\hline$\#$ & Criteria & Requirements \\
\hline & Evaluation Criteria & \\
\hline 1 & Abundant Solar Irradiation & minimum is $1100 \mathrm{kWh} / \mathrm{m}^{2}$ per year \\
\hline 2 & Certain Slope \& Aspect & $\begin{array}{ll}\text { - } & \text { slope }<5-15^{0} ; \\
\text { - } & \text { aspect }=110-200^{\circ} \text { (Southeast, South, partly Southwest) }\end{array}$ \\
\hline 3 & $\begin{array}{l}\text { Transmission Lines Tailored to } \\
\text { Capacity Located Nearby }\end{array}$ & TL with equal and more than $35 \mathrm{kV}$ around $600 \mathrm{~m}$ nearby \\
\hline 4 & Proximity to populated area & $<2500 \mathrm{~m}$ \\
\hline 5 & Proximity to enterprises & $<3500 \mathrm{~m}$ \\
\hline 6 & Proximity to road network & $<500 \mathrm{~m}$ \\
\hline 7 & $\begin{array}{l}\text { Average Air temperature in July } \\
\text { (North Hemisphere) }\end{array}$ & $15-40^{\circ} \mathrm{C}$ \\
\hline 8 & $\begin{array}{l}\text { Proximity to multi-storey houses } \\
\text { (>16 storeys) }\end{array}$ & $>100 \mathrm{~m}$ \\
\hline 9 & Proximity to Residential Areas & $>500 \mathrm{~m}$ \\
\hline & Exclusion Criteria & \\
\hline 10 & Land Cover & $\begin{array}{l}\text { Free of mountains, forests, water bodies, buildings, } \\
\text { wetlands, floodplains; } \\
\text { Preferably low and medium grassy vegetation, shrublands, } \\
\text { barren lands, closed landfills, abandoned mine lands }\end{array}$ \\
\hline 11 & Protected Areas & $\begin{array}{c}\text { National and regional parks, areas of cultural heritage, } \\
\text { paleontological and archeological sites }\end{array}$ \\
\hline 12 & Shoreline & $>1000 \mathrm{~m}$ \\
\hline 13 & High altitude areas & $>1500 \mathrm{~m}$ \\
\hline
\end{tabular}

\section{Results}

The reliability of the Technology for support decision makers in planning renewable solar energy development could be testified and proven in a "pilot" area. As a "pilot" area Zastavna district within Chernivtsi region (Ukraine) with total area 615 sq.km. was chosen (Fig. 2).

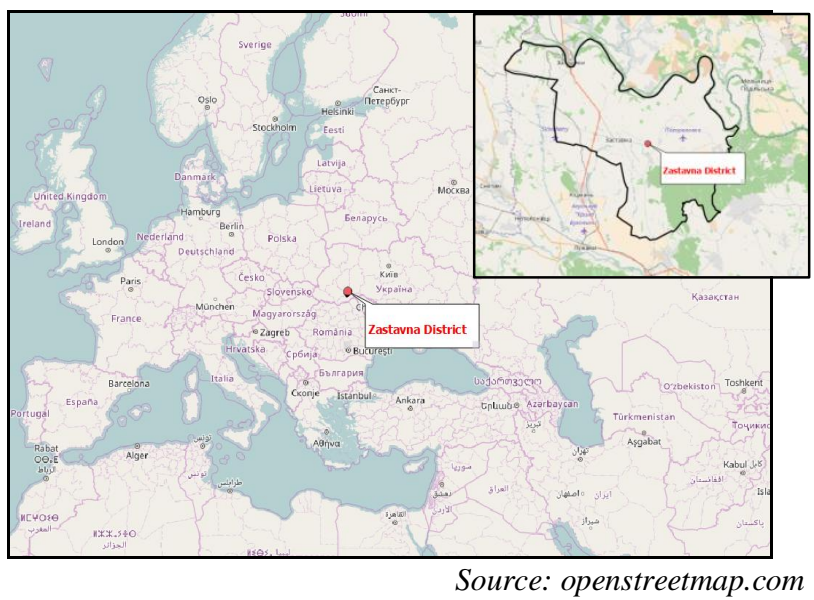

Fig. 2. Location of Zastavna District on OpenStreetMap

After analyzing the "pilot" district, six criteria were chosen for the analysis:
- Certain Slope \& Aspect;

- Transmission Lines Tailored to Capacity Located Nearby;

- Proximity to populated area;

- Proximity to enterprises;

- Proximity to road network;

- Land Cover.

Database of the project consists of two sections: first section - vector files within PostgreSQL Database and second - raster files in file system on PC.

Collection of initial data for the project is conducted according to certain requirements (parameters) for the optimal location of solar power plants.

According to the workflow of the research Data Processing stage is divided into two parts: evaluation and exclusion criteria processing.

Evaluation criteria processing consists of creation of such maps as slope, aspect, transmission lines, road network, settlements, enterprises in QGIS Software, as well as determining the weights for every participating criteria using Analytical Hierarchy Process (AHP) [Saaty T.A.,1992,1997] 
and performing Ordered Weighted Averaging procedure.

The main advantage of AHP method is a complex multi-criteria and multiband model [Siejka M., 2015] where the structure of the problem could be built in a hierarchical perspective, the elements of the structure are marked by significant criteria (factors) that influence the resolution of this problem. Another advantage of this method [Siejka M., Mika M., 2017] is the possibility to combine quantitative and qualitative factors in the process of comparative analyzes. As a result of the conducted analysis, numerical notation of each factor is obtained, which helps avoiding errors in the evaluation.

The final step is to determine the priorities of the results and to rank the alternatives to these solutions.

Result of the procedure - Evaluation Map is shown in Fig. 3.

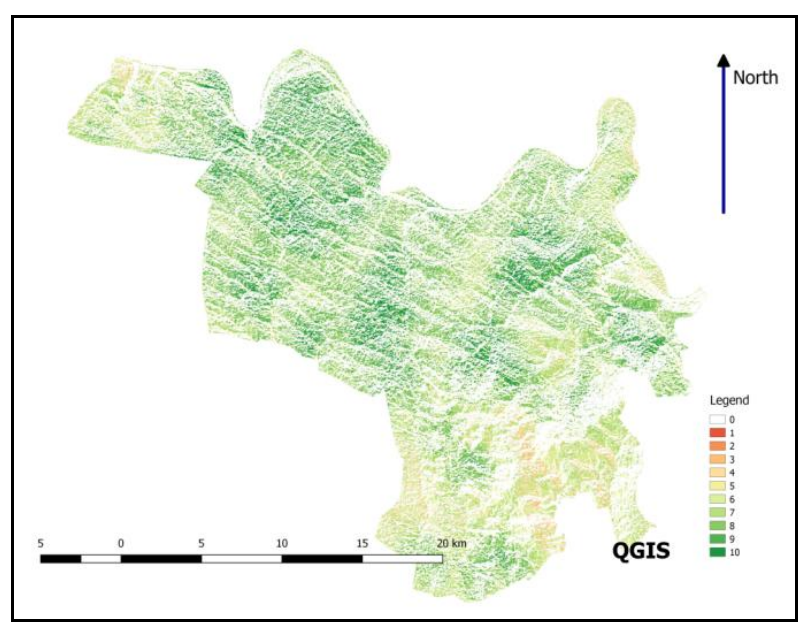

Fig. 3. Resulting Evaluation Map

Green colors indicate the most suitable locations, colors close to orange - least suitable, white - excluded territories with extreme nonsuitable for solar power plant siting slopes and aspects. In Table 2 description of Suitability Scale of Resulting Evaluation Map is shown.

The only exclusion criteria in Zastavna district project is Land Cover. Favorable land cover for solar power plant siting is low and medium grassy vegetation and shrubs.

Landsat 8 OLI/TIRS High level processing Surface Reflectance satellite image with L1TP (Precision Terrain correction) is acquired.

A multispectral image created by a combination of 7,5,2 spectral bands of this satellite system is the best for determination of "pilot" district land cover.
Table 2

Description of Suitability Scale

\begin{tabular}{|c|l|}
\hline Class & \multicolumn{1}{|c|}{ Suitability } \\
\hline 1 & Lowest \\
\hline 2 & Very low \\
\hline 3 & Low \\
\hline 4 & Moderately \\
\hline 5 & Moderate \\
\hline 6 & Moderate high \\
\hline 7 & High \\
\hline 8 & Very High \\
\hline 9 & Extremely High \\
\hline 10 & Highest suitability \\
\hline 0 & Not suitable at all \\
\hline
\end{tabular}

After performing Supervised classification 11 classes of land cover are determined (Fig. 4).

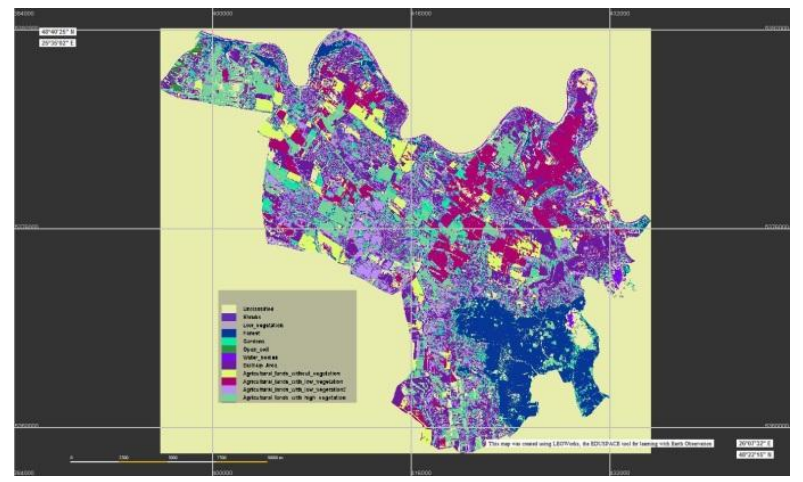

Fig. 4. Results of Supervised Image Classification

As land cover of potential suitable area must be free of mountains, forests, water bodies, buildings, wetlands, floodplains and preferably must have low or medium grassy vegetation or shrublands, it is proposed to eliminate territories in all water bodies, forests, agricultural lands, permanent crops and leave only lands with low or medium grassy vegetation, shrubs, and open soils. Therefore, Mask of Excluded lands is created.

Derived data after previous steps were combined and, as a result, the final Map of Land Suitability for Solar PV power plants is obtained (Fig. 5).

On the basis of final map potential most optimal areas (sites) for solar photovoltaic groundmounted farms' construction are determined (Fig. 6). The total number of sites is 58 , within a total area of 7,44 sq.km (743,91 ha).

After this procedure in order to check the reliability of obtained map, these potential good areas are found on the Public Cadastral Map of Ukraine where user could find all necessary information about location, land use and ownership of land plots within whole country. 


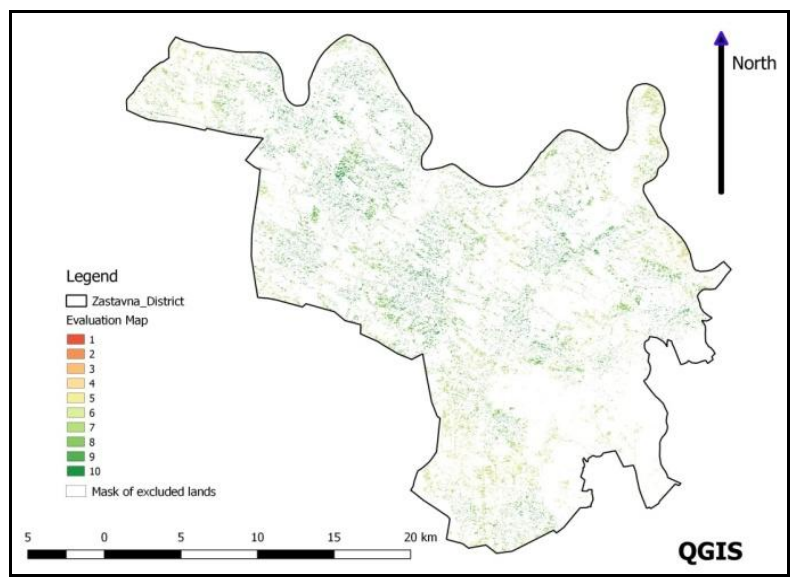

Fig. 5. Map of Land Suitability for Solar PV power plants

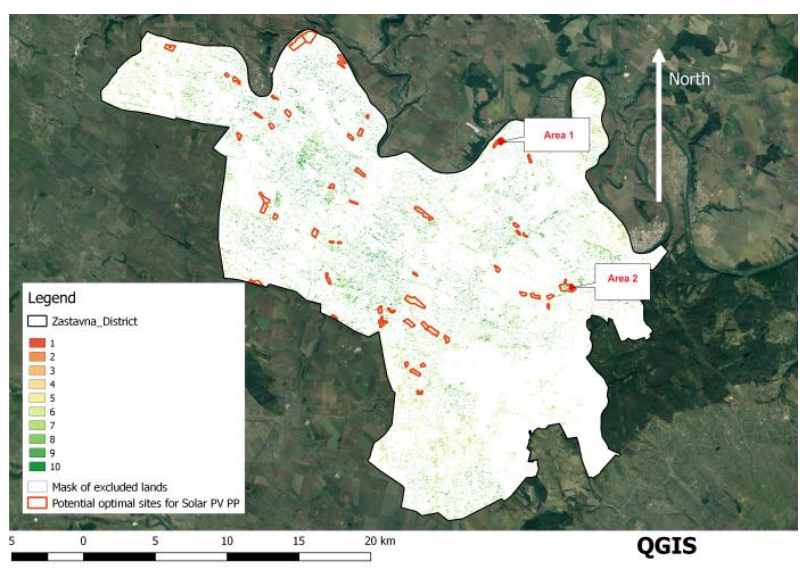

Fig. 6. Potential optimal sites for PV PP

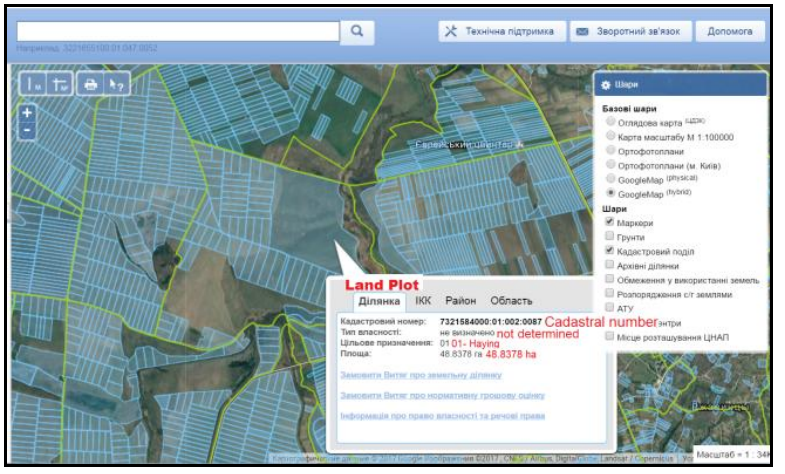

Fig. 7. Public Cadastral Map

One experimental area is chosen for this reliability checking by visual maps` matching. By matching of Final Suitability Map and Aspect Map, it is clear that weighted Overlay Analysis is conducted in right way, as if on chosen Area 1 South, South West, East aspects prevail; according to Public Cadastral Map (Fig. 7) Area 1 mostly covers one land plot with total area 48,8378 ha, its intended use: for haying, type of ownership - not determined. Partly or whole, it could be used for construction of solar PV power plant.

In order to highlight commercial viability of chosen areas it is proposed to estimate how much energy could be produced by establishing on experimental area solar PV farms. By other words, it is to see performance of potential solar gridconnected photovoltaic power plant there.

As a tool for parameters' processing and estimation of grid-connected PV solar farms performance is used "Performance of GridConnected PV Systems" web application of "PVGIS" (EC Joint Research Centre) [Marcel Šúri et al., 2007). Operation there consists of two steps: 1 - to find certain location of a chosen area on the OSM, 2 - to fill the cells with parameters. Therefore, the Annual Performance of a selected area is near $250 \mathrm{MWh}$ with the optimal slope (tilt) of the panels $-36^{0}$. The total loss in this case is $20,3 \%$.

\section{Scientific novelty and practical significance}

A comprehensive analysis of natural factors that influence the choice of the solar farm locations, as well as the use of remote sensing and multicriteria decision analysis methods for obtaining the final map are provided.

It is proposed to classify particular criteria of solar PV farm siting into multiple ranges based on suitability.

For the first time in Ukraine, in particular, in Zastavna district (Chernivtsi region), reliable data for the optimal location of photovoltaic solar power plant construction are obtained. It should be noted that it is proposed to use only data that is freely available on Internet, free open source software.

\section{Conclusions}

This work represents a model which can be easily used to evaluate large areas for optimal site selection for a solar park. Such a model can be very helpful for potential investors to locate potential sites for solar energy utilization, before carrying out a detailed field survey.

The framework of this project consists of a combination of already existing tools such as multicriteria analysis, GIS and remote sensing techniques for spatial analysis, modeling and visualization. 
Finally, it provides accuracy and precision with less evaluation time, allowing for checking the reliability and stability of the results obtained. For these reasons, it may be helpful for potential investors in solar park development and also in other kinds of project siting, due to the generic nature of the framework.

\section{REFERENCES}

Bahadori, A. and Nwaoha, C. A review on solar energy utilization in Australia, Renew. Sust. Energ. Rev., 2013, 18, pp. 1-5.

Brewer J., Ames D. P., Solan D., Lee R., and Carlisle J. "Using GIS analytics and social preference data to evaluate utility-scale solar power site suitability," Renew. Energy, 2015, vol. 81, pp. 825-836.

Carrion, A. J., Estrella, E. A., Dols, A. F., Toro, Z. M., Rodriquez, M., and Ridao, R. A. Environmental decision-support systemsfor evaluating the carrying capacity of land areas: Optimal site selection for grid-connected photovoltaic power plants, Renew. Sust. Energ. Rev., 2008, 12, pp. 2358-2380.

Georgiou A., Skarlatos D. Optimal site selection for sitting a solar park using multi-criteria decision analysis and geographical information systems, Geosci. Instrum. Method. Data Syst., 2016, 5, pp. 321-332.

Kontos, Th., Komilis, D., and Halvadakis, K. Sitting MSW landfills with a spatial multiple criteria analysis methodology, Waste Manage., 2005, 25, pp. 818-832.

LEOWorks 4.0.2339 Documentation. Available from: http://leoworks.terrasigna.com/.

Marcel Š́ri, Thomas A. Huld, Ewan D. Dunlop, Heinz A. Ossenbrink: Potential of solar electricity generation in the European Union member states and candidate countries. Solar Energy, 2007, vol. 81, issue 10, pp. 1295-1305, DOI:10.1016/j.solener.2006.12.007

PostGIS Documentation. Available from: http://postgis.net/documentation/.

PostgreSQL 9.5.7 Documentation. Available from: https://www.postgresql.org/ docs/9.5/static/ index.html.

QGIS 2.18 Documentation. Available from: http:// docs.qgis.org/2.18/en/docs/user_manual/

Saaty T.A. Decision-Making for Leaders. 2nd Ed. RWS Publication, Pittsburgh, USA. United States Geological Survey (USGS), Shutle Radar Topography Mission. 1992.

Saaty T. A. A Scaling Method for Priorities in Hierarchical Structures. Journal of Mathematical Psychology; 1997, pp. 234-281.

Sanchez-Lozano, M. J., Teruel-Solano, J., Soto-Elvira, L. P., Garcia-Cascales, S. M. Geographical Information Systems (GIS) and Multi-Criteria Decision Making (MCDM) methods for the evaluation of solar farms locations: Case study in southeastern Spain, Renew. Sust. Energ. Rev., 2013, 24, pp. 544-556.

Siejka M. Optymalny wybór lokalizacji inwestycji w gospodarce nieruchomościami. Infrastruktura i Ekologia Terenów Wiejskich, № 2015/ IV (2 (Nov 2015)), p. 136, DOI 10.14597/infraeco.2015.4.2.089.

Siejka M., Mika M. Implementation of the AHP Method for Determining the Weights of Factors Decisive for the Location of the Municipal Waste Conversion Plant, on the Example of the City of Krakow, Acta Horticulturae et Regiotecturae, 2017, vol. 20, issue 1, pp. 19-23, DOI: https://doi.org/10.1515/ahr2017-0005.

Tegou,L. I., Polatidis, H., and Haralambopoulos, D. Environmental management framework for wind farm sitting: Methodology and case study, J. Environ. Manage., 2010, 91, pp. 2134-2147.

\section{Л. М. ПЕРОВИЧ ${ }^{1}$, Д. І. КЕРЕУШ ${ }^{2 *}$}

${ }^{1}$ Кафедра кадастру територій, Національний університет “Львівська політехніка”, вул. С. Бандери, 12, Львів, Україна, 79013, тел.: +38 (032) 2582631, ел. пошта: lev.perovych@ gmail.com

${ }^{2}$ Кафедра кадастру територій, Національний університет “Львівська політехніка”, вул. С. Бандери, 12, Львів, Україна, 79013, тел.: +38 (096) 6752001, ел. пошта: dariakereush@ gmail.com

\section{ТЕХНОЛОГІЯ ВИБОРУ ОПТИМАЛЬНОГО МІСЦЯ РОЗТАШУВАННЯ СОНЯЧНИХ ЕЛЕКТРОСТАНЦЙ З ВИКОРИСТАННЯМ ДИСТАНЦЙНОГО ЗОНДУВАННЯ ЗЕМЛІ ТА ГІС-ТЕХНОЛОГІЙ}

Мета. Використання наземних сонячних фотоелектричних електростанцій (СЕС) для виробництва електроенергії протягом останніх десяти років суттєво збільшується по всьому світу. Це зростання обумовлено політичними стимулами, такими як «зелений» тариф, а також низька вартість та висока продуктивність сонячних панелей. Оскільки використання сонячних енергоносіїв зростає, необхідність пошуку кращих місць для їх розташування буде також збільшуватися. Оптимальне розміщення СЕС $\epsilon$ важливе для максимізації корисних характеристик проектів, одночасно мінімізуючи негативні. Зокрема, оптимальне розміщення може максимізувати виробництво електроенергії на таких електростанціях, мінімізуючи витрати, вплив на навколишнє середовище та соціальне середовище. Тому метою $є$ розроблення 
концепції, яка становить інтегрований алгоритм для оцінювання придатності землі для оптимального розміщення сонячних електростанцій. Методика. Запропоновано загальну комплексну основу (алгоритм) для оцінювання придатності земель для оптимального місця розташування сонячних електростанцій, яка $\epsilon$ поєднанням географічної інформаційної системи (ГІС), методів дистанційного зондування Землі (ДЗ3), аналізу та прийняття управлінських рішень. Використано винятково безкоштовне та відкрите програмне забезпечення (Free and Open Source Software). Результати. Доведено достовірність технології для оптимального розташування сонячних електростанцій на території “пілотного" Заставнівського району Чернівецької області (Україна). Опрацювання даних складається з двох частин: опрацювання критерій оцінки та критерій виключення. На результуючий карті придатності земель для розміщення сонячних електростанцій визначено 58 найбільш оптимальних земельних ділянок для будівництва СЕС із загальною площею 7,44 кв. км або 743,91 га - це 1,2 \% площі “пілотного” району. Для висвітлення комерційної життєздатності обраних земельних ділянок запропоновано визначення кількості енергії, яку можна отримати 3 однієї сонячної електростанції, розташованій на експериментальній земельній ділянці. Як інструмент для оцінки продуктивності енергосистеми, використовується веб-додаток "PVGIS" (EU JRC). Визначено, що щорічна продуктивність експериментальної СЕС становить близько 250 МВТ з оптимальним нахилом панелей $36^{\circ}$. Загальна втрата в цьому випадку становить $20,3 \%$. Наукова новизна та практична значущість. Наведено комплексний аналіз природних факторів, що впливають на вибір місця розташування сонячної ферми, а також використання методів дистанційного зондування та методології багатокритеріального аналізу для отримання остаточної карти. Відповідно до літературних оглядів, експертного висновку та міжнародного досвіду запропоновано класифікацію окремих критерій в декількох діапазонах на підставі придатності земель для сонячної енергетики. Вперше в Україні, зокрема, у Заставнівському районі (Чернівецька область) отримані достовірні дані щодо оптимального розташування фотоелектричних сонячних електростанцій. Варто зазначити, що запропоновано використання виключно даних, які $є$ у вільному доступі у мережі Інтернет, а також вільного програмного забезпечення з відкритим кодом.

Ключові слова: сонячні електростанції; технологія; оптимальне місце розташування; критерії; ГІС; ДЗ3.

Received 02.10.2017 